\title{
Variability and Trend of Annual Maximum Daily Rainfall in Northern Algeria
}

\author{
Abderrahmane Nekkache Ghenim and Abdesselam Megnounif \\ "Eau et Ouvrage dans Leur Environnement" Laboratory, Tlemcen University, BP 230, 13000 Tlemcen, Algeria \\ Correspondence should be addressed to Abderrahmane Nekkache Ghenim; anghenim@yahoo.fr
}

Received 3 November 2015; Accepted 7 June 2016

Academic Editor: Robert Tenzer

Copyright ( 2016 A. N. Ghenim and A. Megnounif. This is an open access article distributed under the Creative Commons Attribution License, which permits unrestricted use, distribution, and reproduction in any medium, provided the original work is properly cited.

\begin{abstract}
The daily rainfall dataset of 35 weather stations covering the north of Algeria was studied for a period up to 43 years, recorded after 1970s. The variability and trends in annual maximum daily rainfall (AMDR) time series and their contributions in annual rainfall (AR) were investigated. The analysis of the series was based on statistical characteristics, Burn's seasonality procedure, Mann-Kendall test, and linear regression technique. The contribution of the AMDR to AR analysis was subjected to both the Buishand test and the double mass curve technique. The AMDR characteristics reveal a strong temporal irregularity and have a wide frequency of occurrence in the months of November and December while the maximum intensity occurred in October. The observed phenomenon was so irregular that there was no dominant season and the occurrence of extreme event can arrive at any time of the year. The AMDR trends showed that only six of 35 stations have significant trend. For other stations, no clear trend was highlighted. This result was confirmed by the linear regression procedure. On the contrary, the contribution of AMDR in annual totals exhibited a significant increasing trend for $57 \%$ of the sites studied with a growth rate of up to $50 \%$.
\end{abstract}

\section{Introduction}

Rainfall is a fundamental element of climate which is, for several decades, in perpetual mutations. For most regions around the Mediterranean, these changes resulted in significant rainfall deficits $[1,2]$ accompanied by an increase of exceptional events such as severe droughts and devastating floods [3, 4]. The Mediterranean environments, typical of semiarid regions that enjoy a rather pleasant climate with sunshine and its fine weather, can suffer hazardous situations since several regions are regularly struck by severe rainstorms. Such events are highly variable in the time and space [5] and often lasted less than one day [6]. Therefore, the critical parameter of these rainstorms is the maximum daily rainfall rather than the total rainfall. The annual maximum daily rainfall is defined as an extreme instance, with critical duration for a watershed, region, or state [7]. In the hydrological year, the daily maximum rainfall is the parameter considered to assess the immediate impact on the hydrological response of streams, flooding cities, soil erosion, dams silting, and agricultural production $[8,9]$.
Located on the southern shore of the Mediterranean, Algeria suffers a semiarid to arid climate. Despite a drought that has lasted for over three decades, brief, intense, and devastating floods often affect cities. Due to the intensity of rainfall events that typically last less than 24 hours and the vulnerability of urban areas, the floods have caused damage and significant loss of human lives. The only flood that occurred in the city of Algiers in November 2001 caused some 740 casualties [10-12].

The objective of this study is to contribute to the knowledge of the variability of annual maximum daily rainfall and its changes in the north of Algeria. A particular attention is paid to detect possible trends characterizing AMDR series and to evaluate changes in AMDR contribution to annual totals.

\section{Study Area/Materials and Methods}

The study area is the north of Algeria and covers $15 \%$ of the total surface of the country $\left(2.38\right.$ million $\left.\mathrm{km}^{2}\right)$. The length 


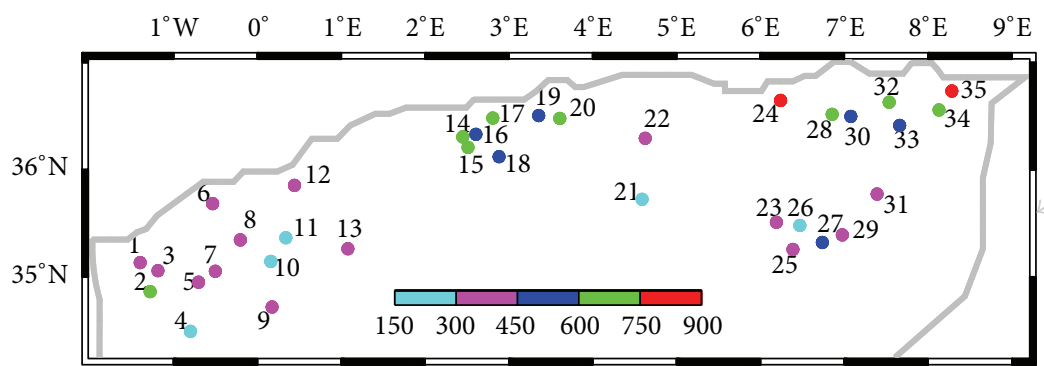

(a)

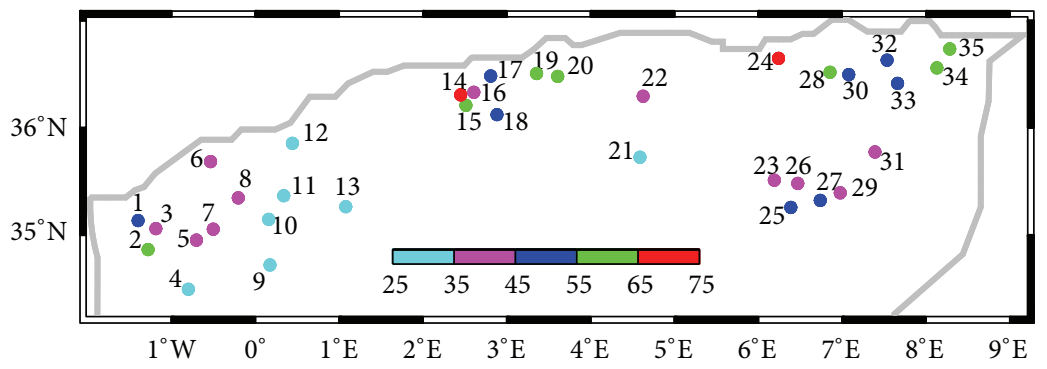

(b)

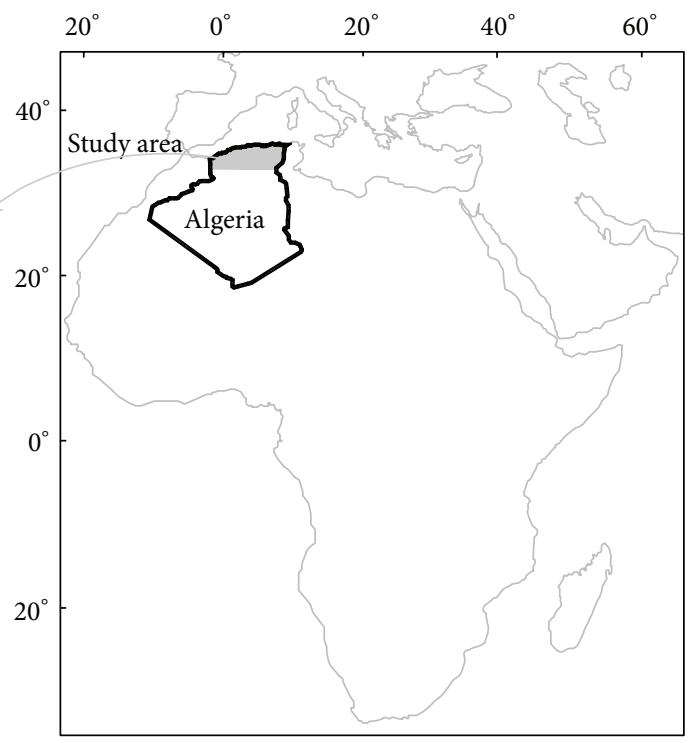

FIGURE 1: Locations of rainfall stations in northern Algeria and mean values intervals of annual rainfall (a) and annual maximum daily rainfall (b).

of the Mediterranean coastline is about $1200 \mathrm{~km}$. Because of its geographic position and its mountainous nature, rainfall shows strongest contrasts between the various areas. This region has a high spatial and temporal climatic variability known as the Mediterranean climate. Intra-annual rainfall is irregular and most rains fall between October and April, while infrequent and local storms occur in the dry season from July to October.

Rainfall data were collected by the National Agency of the Hydraulic Resources (ARNH) (http://www.anrh.dz/). Because there were too many gaps after colonial period in the 1960s and where the number of years of observations was too low for statistical purposes, many station series were discarded from the data set. As a result, only 35 rainfall series were selected (Figure 1).

The data collected are a set of daily rainfall series for the period after 1970. They include less than 5\% of gaps. These are replaced by the values of the station which has the best correlation. The data were tested for their quality control. The suspect data were cross-checked with those of nearby stations (some are not used in this study). The arithmetic sum of daily heights recorded is the annual rainfall value (AR) while the daily maximum observed during the year represents the annual maximum daily rainfall (AMDR). Data were aggregated according to hydrological year from September to August. The selected stations are described by the geographical coordinates, number of years of observation, and statistical characteristics (Table 1).

In the Mediterranean region, it is unlikely that rainstorm lasts more than 24 hours [6]. So, the annual maximum daily rainfall (AMDR) series may be introduced to study the distribution of extreme precipitation occurrences within a year. To examine the regularity for such series, we applied the seasonality as described by Burn [13]. This method used to estimate the timing and regularity of floods was then transposed to extreme rainfall in particular AMDR [14]. It assesses the degree of similarity of watersheds in relation to the hydrological response or the occurrence of extreme rainfall. Burn's vector defined by $(\bar{\theta}, \bar{r})$ represents the variability of the date of occurrence of all extremes events. Its direction is the mean date of the occurrence of the extremes events and the modulus is the variability around the mean value. The dates of the AMDR occurrence are based on the calendar year. January 1 is the 1st day and December 31 is the 365 th day.

Each date $j_{i}$ was replaced by an angle:

$$
\theta_{i}=j_{i} \frac{2 \pi}{365.25}, \quad \theta_{i} \in\left\{0,75^{\circ}, \ldots, 360^{\circ}\right\} .
$$

The obtained series covers the unit circle where each term can be described in polar coordinates as a vector $\left(\cos \theta_{i}, \sin \theta_{i}\right)$, where $\theta_{i}$ indicates the direction expressed in radians. Following the Burn approach, the Cartesian coordinates, $x_{i}=\cos \theta_{i}$ and $y_{i}=\sin \theta_{i}$, are used to evaluate Burn's vector defined by $(\bar{\theta}, \bar{r})$ the mean direction and mean modulus given by the following equations:

$$
\begin{aligned}
& \bar{\theta}=\operatorname{arctg}\left(\frac{\bar{y}}{\bar{x}}\right), \quad \bar{\theta} \in\left[0^{\circ} ; 360^{\circ}\right], \\
& \bar{r}=\sqrt{\bar{x}^{2}+\bar{y}^{2}}, \quad \bar{r} \in[0 ; 1],
\end{aligned}
$$


TABLE 1: Descriptive statistic of AMDR in northern Algeria.

\begin{tabular}{|c|c|c|c|c|c|c|c|c|c|}
\hline \multirow{2}{*}{ Number } & \multirow{2}{*}{ Station } & \multirow{2}{*}{$N$} & \multicolumn{2}{|c|}{ Coordinates } & \multirow{2}{*}{ Average AR (mm) } & \multicolumn{4}{|c|}{$\operatorname{AMDR}(\mathrm{mm})$} \\
\hline & & & Latitude & Longitude & & Average & $\operatorname{Max}$ & $\mathrm{Cv}$ & Cs \\
\hline 1 & Pierre du chat & 41 & $1^{\circ} 26^{\prime} 52^{\prime \prime} \mathrm{W}$ & $35^{\circ} 08^{\prime} 37^{\prime \prime} \mathrm{N}$ & 330 & 46 & 255.4 & 0.81 & 4.60 \\
\hline 2 & Meffrouche & 41 & $1^{\circ} 17^{\prime} 31^{\prime \prime} \mathrm{W}$ & $34^{\circ} 51^{\prime} 19^{\prime \prime} \mathrm{N}$ & 608 & 64 & 158.1 & 0.50 & 1.30 \\
\hline 3 & Bensekrane & 37 & $1^{\circ} 13^{\prime} 26^{\prime \prime} \mathrm{W}$ & $35^{\circ} 04^{\prime} 28^{\prime \prime} \mathrm{N}$ & 377 & 46 & 82.2 & 0.36 & 0.46 \\
\hline 4 & Ras El Ma & 39 & $0^{\circ} 48^{\prime} 34^{\prime \prime} \mathrm{W}$ & $34^{\circ} 29^{\prime} 41^{\prime \prime} \mathrm{N}$ & 194 & 25 & 52.2 & 0.50 & 0.51 \\
\hline 5 & S. A. Benyoub & 42 & $0^{\circ} 44^{\prime} 04^{\prime \prime} \mathrm{W}$ & $34^{\circ} 58^{\prime} 38^{\prime \prime} \mathrm{N}$ & 351 & 35 & 77.2 & 0.42 & 0.85 \\
\hline 6 & Sarno & 41 & $0^{\circ} 35^{\prime} 52^{\prime \prime} \mathrm{W}$ & $35^{\circ} 44^{\prime} 59^{\prime \prime} \mathrm{N}$ & 357 & 40 & 88.7 & 0.45 & 1.48 \\
\hline 7 & Hassi Daho & 40 & $0^{\circ} 32^{\prime} 26^{\prime \prime} \mathrm{W}$ & $35^{\circ} 05^{\prime} 28^{\prime \prime} \mathrm{N}$ & 313 & 38 & 103 & 0.40 & 2.10 \\
\hline 8 & Cheurfas & 35 & $0^{\circ} 15^{\prime} 06^{\prime \prime} \mathrm{W}$ & $35^{\circ} 24^{\prime} 15^{\prime \prime} \mathrm{N}$ & 328 & 38 & 114.4 & 0.56 & 1.93 \\
\hline 9 & Ain El Hadjer & 35 & $0^{\circ} 08^{\prime} 56^{\prime \prime} \mathrm{E}$ & $34^{\circ} 45^{\prime} 25^{\prime \prime} \mathrm{N}$ & 330 & 29 & 61.6 & 0.38 & 1.14 \\
\hline 10 & Ghriss & 38 & $0^{\circ} 09^{\prime} 59^{\prime \prime} \mathrm{E}$ & $35^{\circ} 14^{\prime} 46^{\prime \prime} \mathrm{N}$ & 291 & 31 & 52 & 0.31 & 0.74 \\
\hline 11 & Maoussa & 35 & $0^{\circ} 14^{\prime} 53^{\prime \prime} \mathrm{E}$ & $35^{\circ} 22^{\prime} 41^{\prime \prime} \mathrm{N}$ & 292 & 34 & 84.9 & 0.44 & 1.16 \\
\hline 12 & Oued El Kheir & 41 & $0^{\circ} 22^{\prime} 50^{\prime \prime} \mathrm{E}$ & $35^{\circ} 57^{\prime} 08^{\prime \prime} \mathrm{N}$ & 301 & 31 & 94.4 & 0.50 & 2.16 \\
\hline 13 & Bekhedda & 33 & $1^{\circ} 02^{\prime} 15^{\prime \prime} \mathrm{E}$ & $35^{\circ} 20^{\prime} 32^{\prime \prime} \mathrm{N}$ & 315 & 30 & 64.4 & 0.41 & 0.89 \\
\hline 14 & Meured & 41 & $2^{\circ} 24^{\prime} 27^{\prime \prime} \mathrm{E}$ & $36^{\circ} 26^{\prime} 58^{\prime \prime} \mathrm{N}$ & 615 & 71 & 176.8 & 0.51 & 1.62 \\
\hline 15 & Djebabra & 41 & $2^{\circ} 26^{\prime} 06^{\prime \prime} \mathrm{E}$ & $36^{\circ} 23^{\prime} 43^{\prime \prime} \mathrm{N}$ & 647 & 59 & 176.8 & 0.54 & 1.79 \\
\hline 16 & Ameur El Ain & 41 & $2^{\circ} 34^{\prime} 01^{\prime \prime} \mathrm{E}$ & $36^{\circ} 28^{\prime} 31^{\prime \prime} \mathrm{N}$ & 586 & 40 & 83 & 0.39 & 0.99 \\
\hline 17 & Kolea & 41 & $2^{\circ} 46^{\prime} 19^{\prime \prime} \mathrm{E}$ & $36^{\circ} 38^{\prime} 04^{\prime \prime} \mathrm{N}$ & 606 & 54 & 105.5 & 0.34 & 0.93 \\
\hline 18 & Ouzera & 41 & $2^{\circ} 50^{\prime} 50^{\prime \prime} \mathrm{E}$ & $36^{\circ} 15^{\prime} 21^{\prime \prime} \mathrm{N}$ & 571 & 52 & 134 & 0.46 & 1.38 \\
\hline 19 & Hamiz-D9 & 38 & $3^{\circ} 19^{\prime} 49^{\prime \prime} \mathrm{E}$ & $36^{\circ} 39^{\prime} 26^{\prime \prime} \mathrm{N}$ & 598 & 57 & 102.9 & 0.38 & 0.56 \\
\hline 20 & Lakhdaria & 39 & $3^{\circ} 35^{\prime} 12^{\prime \prime} \mathrm{E}$ & $36^{\circ} 37^{\prime} 40^{\prime \prime} \mathrm{N}$ & 701 & 61 & 117.4 & 0.40 & 1.02 \\
\hline 21 & K'sob & 34 & $4^{\circ} 34^{\prime} 03^{\prime \prime} \mathrm{E}$ & $35^{\circ} 49^{\prime} 32^{\prime \prime} \mathrm{N}$ & 220 & 25 & 53.5 & 0.38 & 1.20 \\
\hline 22 & Sidi Yahia & 40 & $4^{\circ} 37^{\prime} 11^{\prime \prime} \mathrm{E}$ & $36^{\circ} 25^{\prime} 19^{\prime \prime} \mathrm{N}$ & 377 & 35 & 70.1 & 0.33 & 1.00 \\
\hline 23 & Batna & 40 & $6^{\circ} 10^{\prime} 23^{\prime \prime} \mathrm{E}$ & $35^{\circ} 33^{\prime} 53^{\prime \prime} \mathrm{N}$ & 374 & 36 & 64.4 & 0.35 & 0.40 \\
\hline 24 & El Milia & 40 & $6^{\circ} 16^{\prime} 38^{\prime \prime} \mathrm{E}$ & $36^{\circ} 45^{\prime} 21^{\prime \prime} \mathrm{N}$ & 874 & 70 & 210.3 & 0.52 & 1.70 \\
\hline 25 & Ain Tinn & 40 & $6^{\circ} 26^{\prime} 21^{\prime \prime} \mathrm{E}$ & $35^{\circ} 22^{\prime} 39^{\prime \prime} \mathrm{N}$ & 430 & 47 & 143 & 0.46 & 2.44 \\
\hline 26 & Timgad & 40 & $6^{\circ} 28^{\prime} 07^{\prime \prime} \mathrm{E}$ & $35^{\circ} 29^{\prime} 51^{\prime \prime} \mathrm{N}$ & 289 & 33 & 93.7 & 0.44 & 1.93 \\
\hline 27 & Chelia & 43 & $6^{\circ} 39^{\prime} 03^{\prime \prime} \mathrm{E}$ & $35^{\circ} 22^{\prime} 02^{\prime \prime} \mathrm{N}$ & 481 & 52 & 177.5 & 0.56 & 2.65 \\
\hline 28 & Zardasas & 41 & $6^{\circ} 53^{\prime} 48^{\prime \prime} \mathrm{E}$ & $36^{\circ} 35^{\prime} 58^{\prime \prime} \mathrm{N}$ & 658 & 58 & 137 & 0.54 & 1.24 \\
\hline 29 & Ain Mimoun & 40 & $6^{\circ} 57^{\prime} 22^{\prime \prime} \mathrm{E}$ & $35^{\circ} 24^{\prime} 55^{\prime \prime} \mathrm{N}$ & 434 & 43 & 116.1 & 0.41 & 2.32 \\
\hline 30 & Helioplolis & 41 & $7^{\circ} 26^{\prime} 44^{\prime \prime} \mathrm{E}$ & $36^{\circ} 30^{\prime} 32^{\prime \prime} \mathrm{N}$ & 596 & 54 & 103.7 & 0.43 & 0.79 \\
\hline 31 & Ain Beida & 43 & $7^{\circ} 27^{\prime} 03^{\prime \prime} \mathrm{E}$ & $35^{\circ} 47^{\prime} 50^{\prime \prime} \mathrm{N}$ & 408 & 40 & 104 & 0.36 & 2.24 \\
\hline 32 & Ain Berda & 42 & $7^{\circ} 35^{\prime} 47^{\prime \prime} \mathrm{E}$ & $36^{\circ} 41^{\prime} 30^{\prime \prime} \mathrm{N}$ & 631 & 53 & 111 & 0.43 & 0.94 \\
\hline 33 & Bouchegouf & 41 & $7^{\circ} 42^{\prime} 35^{\prime \prime} \mathrm{E}$ & $36^{\circ} 27^{\prime} 33^{\prime \prime} \mathrm{N}$ & 545 & 32 & 120 & 0.41 & 1.12 \\
\hline 34 & Ain Kerma & 41 & $8^{\circ} 11^{\prime} 46^{\prime \prime} \mathrm{E}$ & $36^{\circ} 35^{\prime} 23^{\prime \prime} \mathrm{N}$ & 712 & 57 & 155.1 & 0.47 & 1.41 \\
\hline 35 & Ain Assel & 41 & $8^{\circ} 21^{\prime} 57^{\prime \prime} \mathrm{E}$ & $36^{\circ} 46^{\prime} 03^{\prime \prime} \mathrm{N}$ & 821 & 60 & 142.7 & 0.38 & 1.31 \\
\hline
\end{tabular}

$N$ : years of record; Cv: coefficient of variation; Cs: coefficient of skewness.

where

$$
\begin{aligned}
& \bar{x}=\frac{1}{n} \sum_{i=1}^{n} \cos \theta_{i}, \\
& \bar{y}=\frac{1}{n} \sum_{i=1}^{n} \sin \theta_{i} .
\end{aligned}
$$

When $\bar{r}$ decrease to zero, there is no single dominant season and the occurrence of extreme event can arrive at any time of the year, while $\bar{r}=0$ is a virtual value indicating that extreme events occur on the same day. The date of occurrence of extreme events is regular, as the modulus approaches the unit more.

The annual trend of AMDR series was analyzed by using two statistical methods: the Mann-Kendall test and the linear regression. The nonparametric Mann-Kendall test $[15,16]$ detects the direction of trend patterns in hydrological variables. For a time series $\left(x_{i}\right)$ of $n$ values, each value $x_{i}$ is compared with all corresponding $x_{j}$ to compute the sign, and the indices $i$ and $j$ take the respective values $i=1,2, \ldots, n-1$ and $j=i+1, i+2, i+3, \ldots, n$. Kendall's $S$-statistics is based on the sum and variance computation. In this study, an error risk of $5 \%$ is accepted; that means a probability threshold below which the null hypothesis, the trend series, is monotonic, will 
be rejected. Thereby, the Mann-Kendall test is expected to be less affected by the outliers because its statistic is based on the sign of differences rather than on the values of the random variable [17].

The linear regression procedure is a statistical technique for estimating the relationships among variables (e.g., $X$ and $Y)$. The straight line $Y=a X+b$ is obtained by the least square regression method. The slope $(a)$ indicates the average rate of change in the variable used. If the change is significantly different from zero, then a real change occurs. Positive slope defines increasing trend while the negative one indicates a decreasing trend.

The temporal series of the rate contribution of the AMDR to annual rainfall was subjected to the Buishand test to assess trends and date of departure of homogeneity [18]. The test is a graphical method based on the evolution of the following equation:

$$
\mathrm{CS}_{k}(X)=\sum_{i \leq k} S_{i}=\sum_{i \leq k}\left(\frac{X_{i}-\bar{X}}{s}\right),
$$

where $X_{i}$ is the variable, $\bar{X}$ is the mean value of the series, and $s$ is the standard deviation.

The statistical parameter $\max _{k}\left|\mathrm{CS}_{k}\right|$ is a good indicator of the departure of homogeneity [19]. The increasing or decreasing limbs of both sides of the extremum $\max _{k}\left|\mathrm{CS}_{k}\right|$ correspond to surplus or deficit periods, respectively. So when significant change is confirmed, we applied the double mass curve to quantify the surplus or deficit [20]. The curve is a straight line whose slope is the proportionality constant. A break in slope indicates a change of the proportionality [21]. The break in slope and the angle formed by two straight lines indicate the date and the degree of change in the behavior of the phenomenon.

\section{Results}

In the study sites located in the north of Algeria where a division in increments of $150 \mathrm{~mm}$ is shown in Figure 1(a), the average annual rainfall varies from $194 \mathrm{~mm}$ (Ras El Ma station, code number 4) to $874 \mathrm{~mm}$ (El Milia station code number 24) (Table 1). Spatially, rainfall is distributed in four areas [22]:

(i) The central highlands, Sersou and Ras El Ma regions, though situated at high altitude, are sheltered compared to wet currents, where rainfall is less than $300 \mathrm{~mm}$.

(ii) The western region of the country is characterized by a relative sheltered position compared to maritime influences and the low volume of the relief. Annual averages are generally less than $450 \mathrm{~mm}$.

(iii) The mountainous areas and high interior plains (mountains of Tlemcen in the west and the mountains of Zaccar and Dahras in the east) are characterized by the relative importance of total rainfall, with annual average exceeding $600 \mathrm{~mm}$. (iv) The Atlas Tellien region exposed to the north and northwest records rainfall amounts that can exceed $800 \mathrm{~mm}$.

For AMDR values, a division in increments of $10 \mathrm{~mm}$ and the main statistical parameters estimated for all the stations are shown, respectively, in Figure 1(b) and Table 1. Spatial variability of intra-annual averages of AMDR ranges from a minimum of $25 \mathrm{~mm}$ (station Ras El Ma, code number 4) to a maximum of $71 \mathrm{~mm}$ (Station Meured, code number 14). Low values are concentrated on the west side while the high values are in the east and center of the country.

Through the 35 studied stations, the temporal distribution of the annual maximum daily rainfall is irregular. The coefficients of variation, $\mathrm{Cv}$, vary between $31 \%$ and $81 \%$, with a spatial average of $44 \%$. The most irregular series, $\mathrm{Cv}$ above 0.5 , are found near the reliefs. The stations with the code numbers 1 and 24 are positioned facing the north and the stations with code numbers $2,4,8,12,14,15,24,27$, and 28 are positioned facing the south (Figure 1). The largest values of 255 and $210 \mathrm{~mm}$ were recorded, respectively, in the west region in station code number 1 in 1999-2000 and at the east in station code number 24 in 1990-1991. The spatial average of maximum daily rainfall is about $114 \mathrm{~mm}$, which represents $24 \%$ of the spatial average of mean inter annual rainfall.

For stations under consideration, the skewness coefficient (Cs) has positive values fluctuating from 0.4 to 4.6 with a spatial mean of 1.43 . Thereby, at level confidence of $95 \%$, there is rejection for normal distribution for a majority of stations since the values of skewness coefficient are above 0.62 for 31 of 35 stations. That means low values are more frequent while high values are still rare but excessive. The pronounced skewness coefficients occurred at the station Pierre du chat (code number 1).

The difference in positioning stations (near the coastline, facing the sea, at high altitude or between the mountains) prevents a relatively good correlation to the altitude. The spatial variability of rainfall (AR and AMDR) is mainly influenced by latitude (Figure 2). The average increase for $\mathrm{AR}$ and AMDR, respectively, is about $140 \mathrm{~mm}$ and $25 \mathrm{~mm}$ to $100 \mathrm{~km}$ latitude.

The occurrence of AMDR was more frequent during November, followed by December and January (Figure 3(a)), while the peaks in order of importance occurred in October, December, and November (Figure 3(b)). In addition, the seasonal concentration index $\bar{r}$ varies from 0.03 to 0.32 with an average of 0.15 (Figure 4 ). So, there is no single dominant season and the occurrence of an extreme event can arrive at any time of the year. On the other hand, Burn's method shows that AMDR were more concentrated in February through $40 \%$ of the stations, against $20 \%$ in October (Figure 4 ).

The results of the Mann-Kendall test are summarized in Table 2 and Figure 5(a). At the 95\% confidence level, only 6 of 35 stations show significant trend. The stations Ras El Ma, Ain Berda, and Chelia show an increasing trend, whereas the trend is decreasing in Sarno, Ameur El Ain, and Djebabra, while in the remaining stations no significant trend is observed. This finding corroborates the results obtained by the linear regression analysis (Table 2 and Figure 5(b)). 


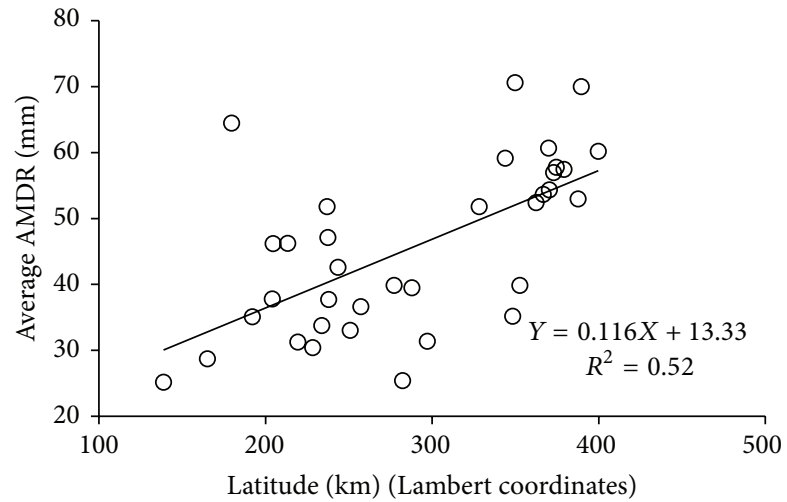

(a)

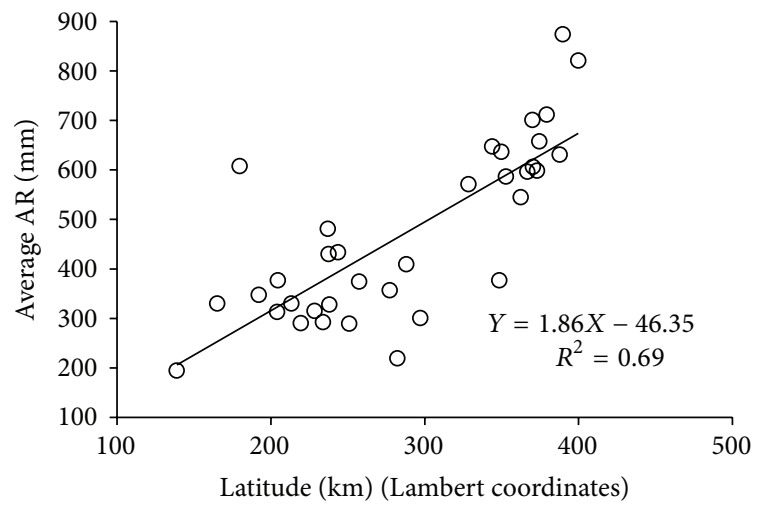

(b)

FIGURE 2: Relationship of AMDR (a) and AR (b) with latitude in northern Algeria.

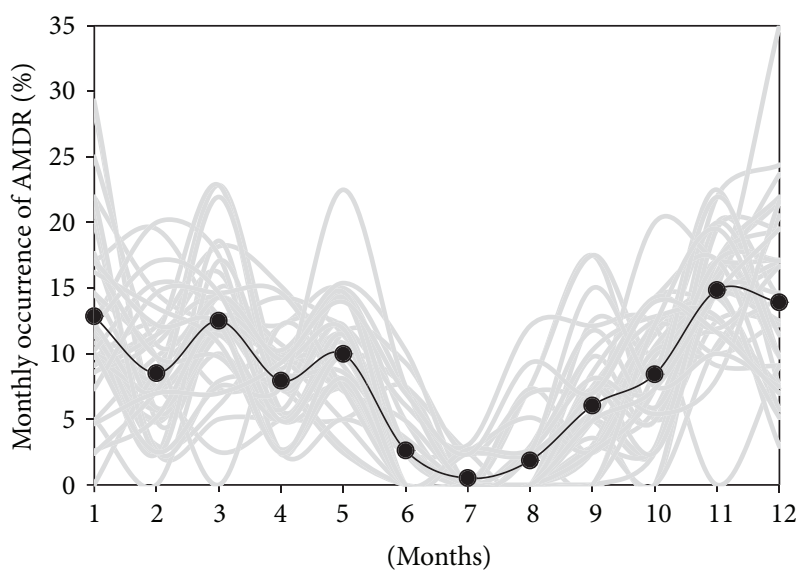

Grey: monthly occurrence of AMDR for individual stations Black: monthly average occurrence of AMDR

(a)

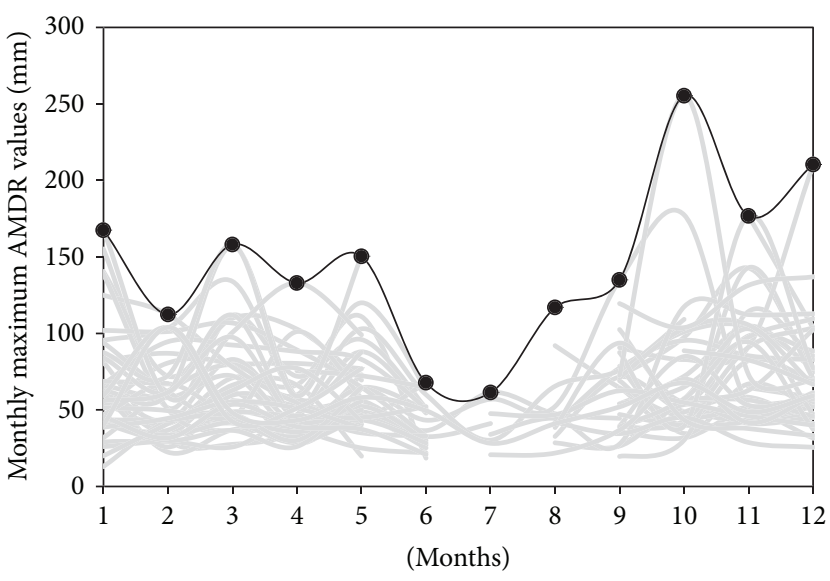

Grey: monthly maximum AMDR values for individual stations Black: monthly maximum AMDR values for all stations

(b)

FIgURE 3: Annual maximum daily rainfall (AMDR) frequency (a) and maximum values (b) at monthly scales.

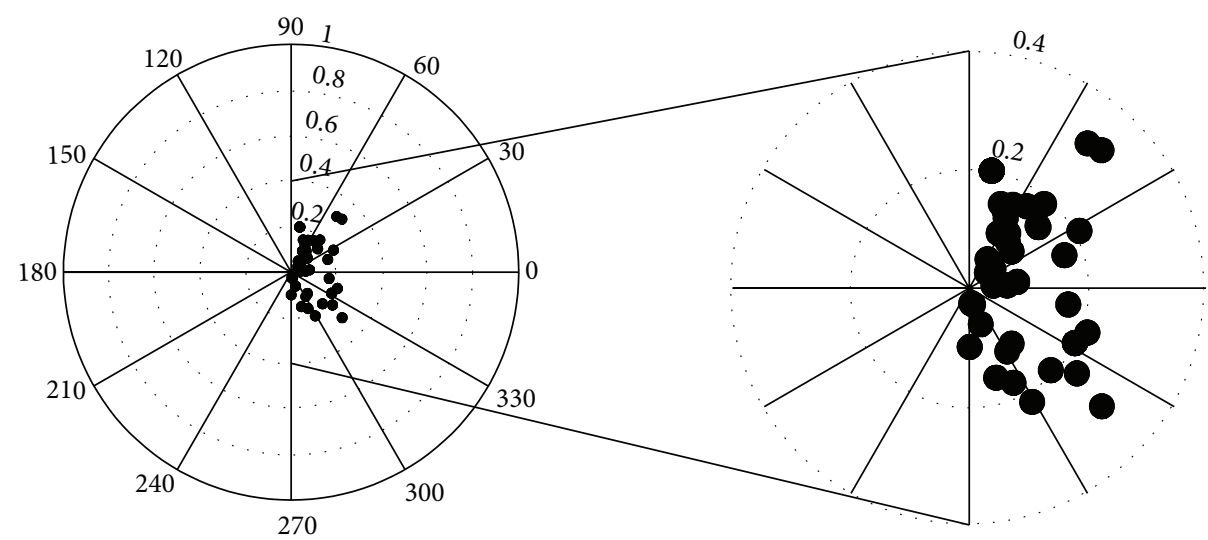

FIgURE 4: Location of seasonal concentration index $\bar{r}$ for AMDR. The angles: $0^{\circ}$ represents January $1 ; 90^{\circ}$ represents April $1 ; 180^{\circ}$ represents July 1 ; and $270^{\circ}$ represents October 1. 
TABLE 2: $P$ values and Tau of Mann-Kendall test, the slope $(a)$ of linear regression analysis, and AMDR contribution to AR over the period after 1970 in the north of Algeria.

\begin{tabular}{|c|c|c|c|c|c|c|}
\hline \multirow{2}{*}{ Number } & \multirow{2}{*}{ Station } & \multicolumn{2}{|c|}{ Mann-Kendall test } & \multirow{2}{*}{$\begin{array}{c}\text { Linear regression } \\
\text { Slope }(a)\end{array}$} & \multicolumn{2}{|c|}{ AMDR contribution to AR } \\
\hline & & $P$ value & Tau & & Date of change & $\%$ deficit $(-)$ or surplus $(+)$ \\
\hline 1 & Pierre du chat & 0.167 & -0.151 & +0.118 & 2001 & +34.9 \\
\hline 2 & Meffrouche & 0.078 & -0.193 & -0.872 & & Complex \\
\hline 3 & Bensekrane & 1.000 & +0.002 & +0.024 & 1987 & +41.2 \\
\hline 4 & Ras El Ma & $0.002^{*}$ & +0.022 & +0.353 & 1999 & +22.9 \\
\hline 5 & S. A. Benyoub & 0.374 & +0.104 & +0.286 & 1987 & +25.3 \\
\hline 6 & Sarno & $0.047^{*}$ & -0.217 & -0.427 & & Complex \\
\hline 7 & Hassi Daho & 0.305 & -0.114 & -0.027 & 1997 & +27.8 \\
\hline 8 & Cheurfas & 0.787 & -0.034 & +0.158 & 1986 & +29.6 \\
\hline 9 & Ain El Hadjer & 0.822 & -0.029 & -0.140 & 1988 & -17.4 \\
\hline 10 & Ghriss & 0.874 & -0.024 & -0.089 & 1983 & +42.6 \\
\hline 11 & Maoussa & 0.287 & +0.128 & +0.335 & & Complex \\
\hline 12 & Oued El Kheir & 0.928 & +0.011 & +0.032 & 1997 & +18.9 \\
\hline 13 & Bekhedda & 0.687 & +0.051 & +0.061 & 1991 & +18.3 \\
\hline 14 & Meured & 0.240 & -0.129 & -0.437 & & Complex \\
\hline 15 & Djebabra & $0.001^{*}$ & -0.368 & -1.223 & 1985 & -22.7 \\
\hline 16 & Ameur El Ain & $<10^{-3 *}$ & -0.431 & -0.802 & & Complex \\
\hline 17 & Kolea & 0.574 & -0.062 & -0.045 & 1990 & +07.9 \\
\hline 18 & Ouzera & 0.084 & -0.189 & -0.588 & & No trend \\
\hline 19 & Hamiz-D9 & 0.372 & -0.102 & -0.349 & & Complex \\
\hline 20 & Lakhdaria & 0.200 & -0.145 & -0.301 & 1990 & +8.5 \\
\hline 21 & K'sob & 0.778 & -0.036 & -0.057 & 1981 & +18.4 \\
\hline 22 & Sidi Yahia & 0.577 & +0.066 & +0.034 & 1987 & -18.8 \\
\hline 23 & Batna & 0.576 & +0.063 & +0.093 & & No trend \\
\hline 24 & El Milia & 0.363 & +0.101 & +0.285 & 1981 & +49.9 \\
\hline 25 & Ain Tinn & 0.651 & +0.111 & -0.166 & 1985 & +12.2 \\
\hline 26 & Timgad & 0.402 & +0.094 & +0.275 & 1992 & +10.0 \\
\hline 27 & Chelia & $0.013^{*}$ & +0.265 & +0.664 & & No trend \\
\hline 28 & Zardasas & 0.357 & +0.101 & +0.293 & 1979 & +29.6 \\
\hline 29 & Ain Mimoun & 0.807 & -0.028 & +0.042 & 1986 & -11.01 \\
\hline 30 & Helioplolis & 0.200 & +0.140 & +0.425 & 1991 & +28.1 \\
\hline 31 & Ain Beida & 0.944 & -0.009 & -0.151 & 1989 & -12.1 \\
\hline 32 & Ain Berda & $0.032^{*}$ & +0.232 & +0.601 & 1987 & +14.2 \\
\hline 33 & Bouchegouf & 0.094 & +0.183 & +0.411 & 1998 & +33.2 \\
\hline 34 & Ain Kerma & 0.551 & -0.066 & -0.255 & & Complex \\
\hline 35 & Ain Assel & 0.142 & +0.161 & +0.345 & 1990 & +14.2 \\
\hline
\end{tabular}

${ }^{*}$ Trend statistically significant at $5 \%$ level.

Indeed, for 34 stations the slope $(a)$ is less than $|1|$ leading to stationarity of the series. The only Djebabra station shows a moderate decreasing trend.

The curves resulting from Buishand procedure were classified into four distinct cases. The first case concerns five rainfall stations (Ain Beida, Ain El Hadjer, Sidi Yahia, Aïn Mimoun, and Djebabra) where $\mathrm{Cs}_{k}$ curve shows ascending and descending lambs, and the maximum of the $\mathrm{Cs}_{k}$ curve corresponds to the date of change (Figure 6(a)). The decline of the AMDR contribution to annual rainfall, manifested by the falling lamb, was quantified by the double mass curve and varies between 12.1 and $22.7 \%$. The dates of change were observed during the 1980s (Table 2). The second case grouped 20 rainfall series exhibiting opposite behavior (Figure 6(b)). The AMDR contribution has increased significantly (e.g., at El Milia station the increase reaches about 50\%). The dates of change occurred from the end of 1970s to the end of 1990s. The third case represents seven of 35 rainfall series and is manifested by a complex form showing more than one date of the change. However, lambs of the $\mathrm{Cs}_{k}$ curves were not sufficiently long to apply the double mass method (Figure 6(c)). For the last case, three of 35 rainfall series, no clear trend can be detected for any rainfall sequence (e.g., Ouzera, Batna, and Chelia) (Figure 6(d)). 


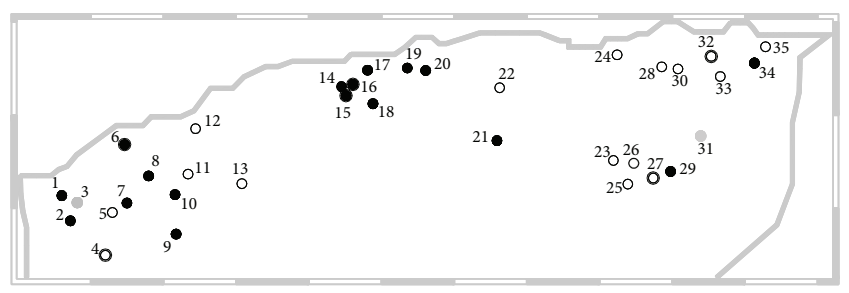

- Increasing trend

- Decreasing trend

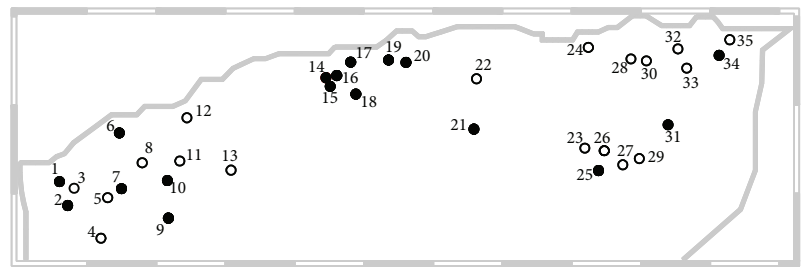

○ Increasing trend

- Decreasing trend

(b) Linear regression trend

Figure 5: Mann-Kendall (a) and linear regression (b) trend of AMDR over the period after 1970 in northern Algeria.

\section{Discussion and Conclusion}

The data of 35 rainfall stations recorded after 1970 and covering the north of Algeria reveal that rainfall undergoes an overall downward trend. Deficit rate between 20 and $40 \%$ was estimated in several parts of the country [2327]. This decrease in annual rainfall was accompanied by a large temporal irregularity like the Mediterranean region $[28,29]$. In terms of AMDR values, coefficients of variation for the different sites vary at $\pm 12 \%$ around the average of $44 \%$ showing a more pronounced irregularity occurrence, but in the same proportions as in other regions [30-32]. Indeed, the skewness values of the time series, which show if the empirical distribution of the data follows a normal distribution, are more important in the extreme east of the country than in the west and the center (a ratio of 1.66). All positive values of Cs found indicating that distribution shifted to the left of the median (Table 1) are of the same order as those of Chott-Chergui basin in western Algeria [33]. In this analysis, we exclude Pierre du chat station for which an exceptional value of $255.4 \mathrm{~mm}$ has increased all coefficients.

For a better understanding of water availability, it is very interesting to demarcate the quasi-homogeneous climatic zones and identify the climatic subregions in an observation network [34]. Nevertheless, in the north of Algeria, the proximity of the Mediterranean and the variety surrounding reliefs make it difficult to delimiting homogeneous areas. Moreover, the increased baroclinic instability in saturated air is closely related to latent heat release and thus to the development of convective phenomena. During the rainy season, northern Algeria is affected by the polar front, especially the east of the country. Further south, the highlands are generally affected by western disturbances following the orographic forcing that causes thunderstorms with heavy rainfall [35]. Then, the correlation between rainfall and altitude is complex. It may be valid only for limited areas. Contrary to that, the rainfall is positively correlated with latitude and the east of the country is much wetter than the west (Figure 2).

For almost all stations, mean values of AMDR as well as AR are two to five times higher for particular years. This disparity between the average values and peaks combined with statistical parameters cited above is illustrated in Figure 4 according to Burn [13]. The seasonal concentration index $\bar{r}$ varies between 0.03 and 0.32 showing that there is no single dominant season, and the time of the occurrence of an extreme event is distributed around the year. This demonstrates the extent of rainfall irregularity in the south of the Mediterranean. This is not always the case through other regions. In central Slovakia, for example, the phenomenon has a spatiotemporal occurrence more regular [14]. Despite this, October and November are the months when the floods are the deadliest. It should be noted that Algeria is the country where the number of flood victims is the highest of the Mediterranean countries [36].

The examination of AMDR trends using the MannKendall test and linear regression procedure shows that, unlike the annual rainfall undergoing a downward trend in most of the rainfall stations in Algeria [28, 37-39], there is no clear trend to rise or fall in the series of AMDR for the majority of the sites studied. The region of study is characterized by a great number of complexities related to geography and topography where the combination of the effects produced makes weather forecasting exceedingly difficult causing high spatiotemporal variability. So, like many other parts of the Mediterranean area, a majority of AMDR series recorded in the north of Algeria show nonsignificant trends [38, 40, 41]. However, globally, AMDR series show an increase in tendency in the east of the country and a decrease in the center while in the west, the system is more complicated and there is no majority of stations that differs from others. In this context, the IPCC report confirmed that the behavior of extreme rainfall differs considerably from the annual totals by some considerable geographical differences in the frequency, timing, and magnitude of events [42].

The present study does not converge with the results developed by some authors and in the occurrence of extreme rainfall forecasts which predict an increase in extreme rainfall in many parts of the world, even in areas where the average annual rainfall has a downward trend [42-45]. For some authors, this finding is apparently valid for Mediterranean countries that record rainfall deficits since 3-4 decades $[3,28]$. However, our study reveals that not only does the trend of the AMDR series depend on global and regional settings, but also, it is highly influenced by local geographical characteristics. This result corroborates the finding of Tramblay et al. [38] and Jones et al. [46] who cited the orography influence as a main cause generating local climatic processes. Other 

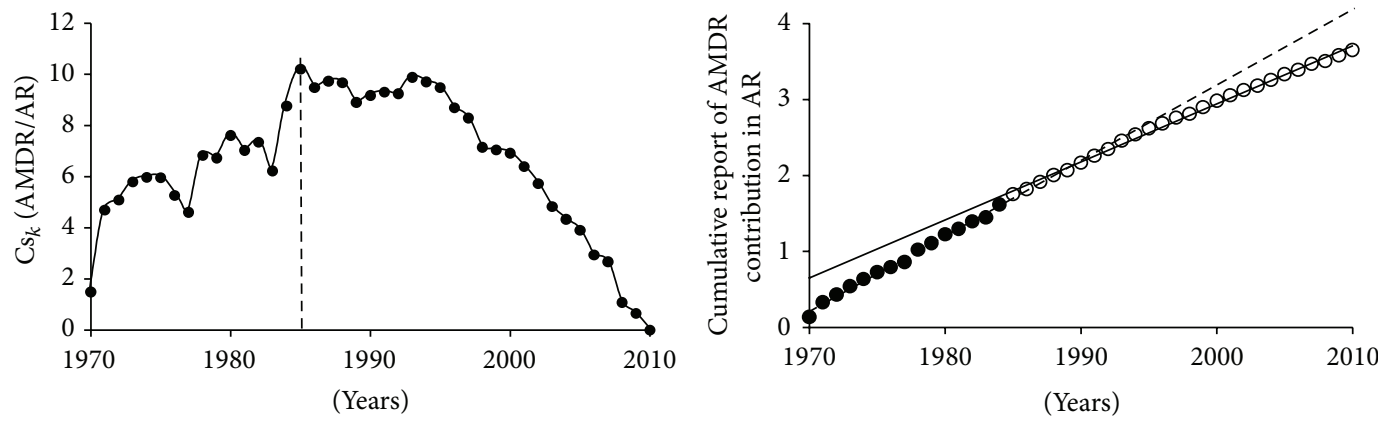

- Before date of change

- After date of change

(a)
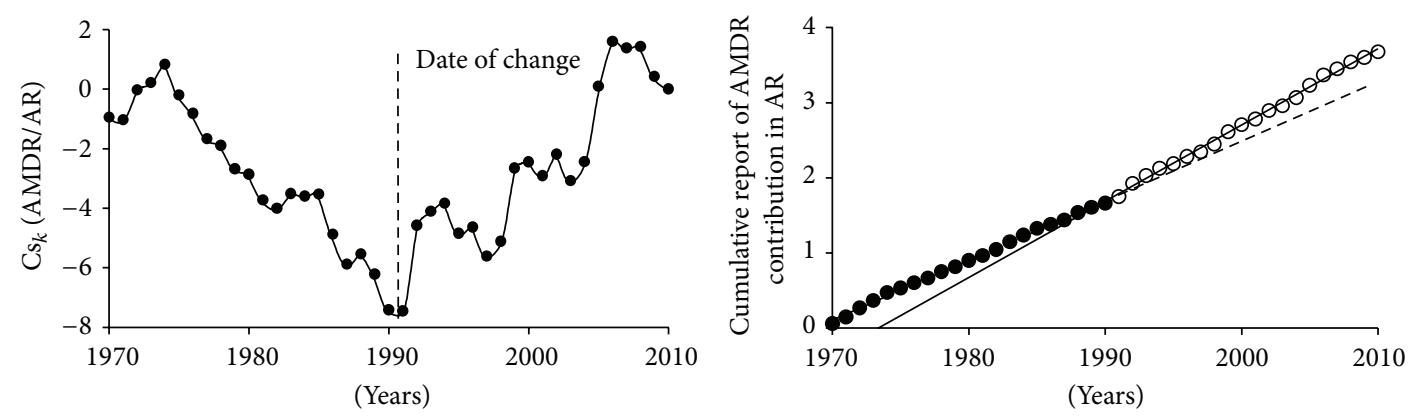

- Before date of change

$\circ$ After date of change

(b)
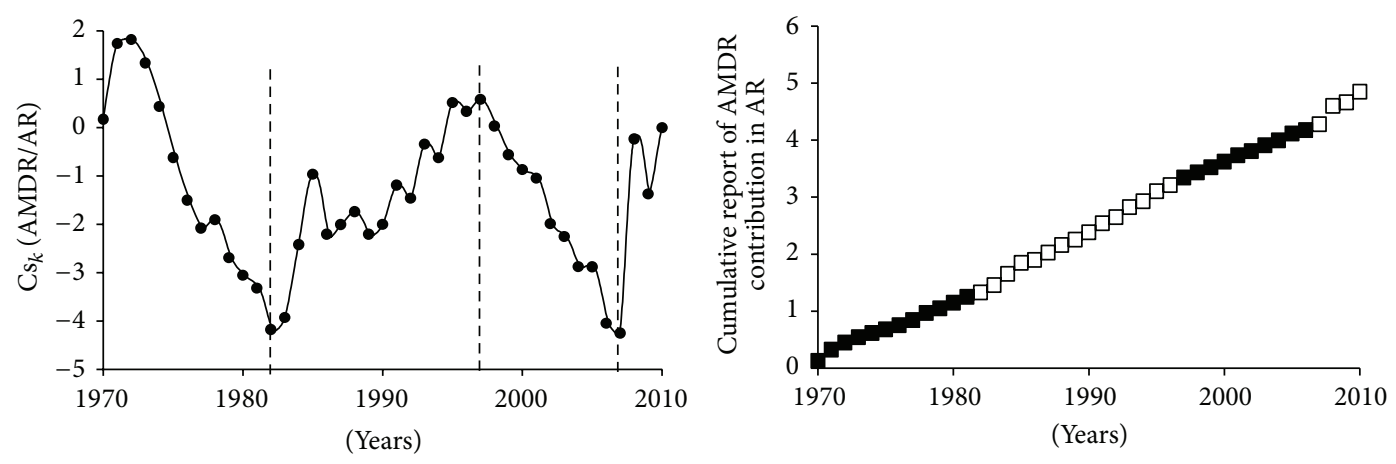

$\square$ Increasing trend

- Decreasing trend

(c)
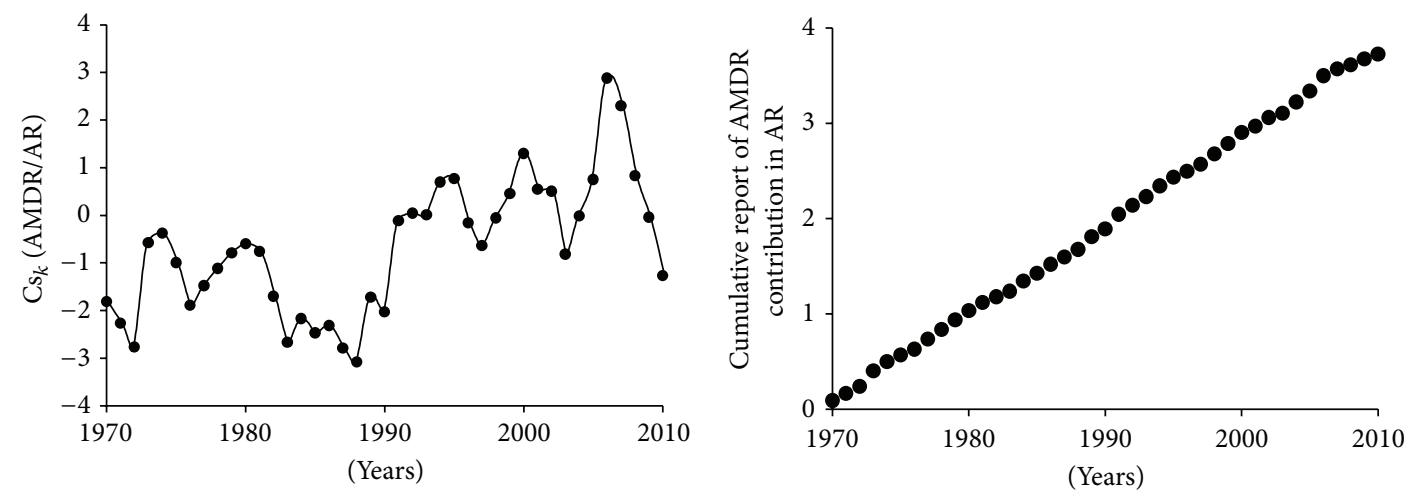

(d)

FIGURE 6: Buishand and double mass methods applied to AMDR contribution to AR. 
investigations of extreme rainfall across many countries of the globe show that extreme rainfall trend is complex. For example, it had increased in the USA, China, Australia, Canada, Norway, Mexico, and Poland [47], where no clear trend was detected in other regions such as in Brazil and Ethiopia [7, 48]. Although a general trend for drought and a reduction in rainfall intensity was predicted for eastern Mediterranean [49], the extreme precipitation trend is more misunderstood as in Jordan [32].

Without having a provided dominant season, the AMDR occurred mainly between October and March (Figure 4) and the highest values were recorded in autumn (Figure 3). Similar results were observed in other Mediterranean sites where a slight increase in autumn rainfall was mainly felt in October [50,51], leading to more concentrated rainfall during the hydrological year [52].

The relationship between the values of the AMDR and $\mathrm{AR}$ in the north of Algeria has experienced significant temporal changes in most of the studied stations. However, four configurations of the relationship between AMDR and AR (Figure 6) are distinguished and seem to be related to the climate change which operated in the Mediterranean region. Despite the lack of trend in AMDR series, their contributions in the annual rainfall are on the rise. This occurred in $80 \%$ of stations spread from the east to the west (not taking into account the stations that submitted a complex or nonsignificant trend behavior). The rate of increase of this contribution will be from 8 to about $50 \%$. Although the rates of reduction of annual precipitation in the post-1970 period are higher than $20 \%$ for most stations in Algeria, some very high rates of increase in the contribution of the AMDR in annual totals are amplified by extremely high values of the recorded AMDR (example of El Milia Station). In this context and by analyzing the contribution of events in annual precipitation in the north of the Mediterranean, De Luis et al. [53] reported that, in all the studied stations, more than $37 \%$ experienced an increasing contribution against $15 \%$ with decreasing contribution.

The start of the change leading to the increasing contribution of the AMDR to the annual rainfall occurred mainly during the 1980s and 1990s and the AMDR occurred principally in the autumn season. However, this observation is misleading because the decrease of annual rainfall is mainly due to the sharp diminution of the winter rainfall. Indeed, the values of the AMDR that occurred during autumn are in the same proportions observed in winter (Figure 3). In the Mediterranean region, Giorgi and Lionello [50] observed a sharp falling in the winter rainfall against a small increase in autumn. They mainly attributed the increase in extreme daily intensities to the reduction of annual precipitation. The rate of this reduction was estimated to be more than $30 \%$ in the northwest of Algeria [54].

\section{Competing Interests}

The authors declare that there is no conflict of interests regarding the publication of this paper.

\section{References}

[1] A. Longobardi and P. Villani, "Trend analysis of annual and seasonal rainfall time series in the Mediterranean area," International Journal of Climatology, vol. 30, no. 10, pp. 1538-1546, 2010.

[2] P. T. Nastos, "Trends and variability of precipitation within the Mediterranean region, based on Global Precipitation Climatology Project (GPCP) and ground based datasets," in Advances in the Research of Aquatic Environment, vol. 1, pp. 67-74, Springer, 2011.

[3] P. Alpert, T. Ben-Gai, A. Baharad et al., "The paradoxical increase of Mediterranean extreme daily rainfall in spite of decrease in total values," Geophysical Research Letters, vol. 29, no. 11, pp. 1-31, 2002.

[4] A. Bodini and Q. A. Cossu, "Vulnerability assessment of Central-East Sardinia (Italy) to extreme rainfall events," Natural Hazards and Earth System Science, vol. 10, no. 1, pp. 61-72, 2010.

[5] S. Beguería, S. M. Vicente-Serrano, J. I. López-Moreno, and J. M. García-Ruiz, "Annual and seasonal mapping of peak intensity, magnitude and duration of extreme precipitation events across a climatic gradient, northeast Spain," International Journal of Climatology, vol. 29, no. 12, pp. 1759-1779, 2009.

[6] T. Haktanir, S. Bajabaa, and M. Masoud, "Stochastic analyses of maximum daily rainfall series recorded at two stations across the Mediterranean Sea," Arabian Journal of Geosciences, vol. 6, no. 10, pp. 3943-3958, 2013.

[7] J. R. Porto de Carvalho, E. D. Assad, A. F. de Oliveira, and H. Silveira Pinto, "Annual maximum daily rainfall trends in the midwest, southeast and southern Brazil in the last 71 years," Weather and Climate Extremes, vol. 5, no. 1, pp. 7-15, 2014.

[8] M. J. M. Römkens, K. Helming, and S. N. Prasad, "Soil erosion under different rainfall intensities, surface roughness, and soil water regimes," Catena, vol. 46, no. 2-3, pp. 103-123, 2002.

[9] X.-C. Zhang and W.-Z. Liu, "Simulating potential response of hydrology, soil erosion, and crop productivity to climate change in Changwu tableland region on the Loess Plateau of China," Agricultural and Forest Meteorology, vol. 131, no. 3-4, pp. 127142, 2005.

[10] G. J. Tripoli, C. M. Medaglia, S. Dietrich et al., "The 9-10 November 2001 Algerian flood: a numerical study," Bulletin of the American Meteorological Society, vol. 86, no. 9, pp. 12291235, 2005.

[11] S. Argence, D. Lambert, E. Richard et al., "High resolution numerical study of the Algiers 2001 flash flood: sensitivity to the upper-level potential vorticity anomaly," Advances in Geosciences, vol. 7, pp. 251-257, 2006.

[12] N. Söhne, J.-P. Chaboureau, S. Argence, D. Lambert, and E. Richard, "Objective evaluation of mesoscale simulations of the Algiers 2001 flash flood by the model-to-satellite approach," Advances in Geosciences, vol. 7, pp. 247-250, 2006.

[13] D. H. Burn, "Catchment similarity for regional flood frequency analysis using seasonality measures," Journal of Hydrology, vol. 202, no. 1-4, pp. 212-230, 1997.

[14] J. Szolgay, J. Parajka, S. Kohnová, and K. Hlavčová, “Comparison of mapping approaches of design annual maximum daily precipitation," Atmospheric Research, vol. 92, no. 3, pp. 289-307, 2009.

[15] H. B. Mann, "Nonparametric tests against trend," Econometrica, vol. 13, pp. 245-259, 1945.

[16] M. G. Kendall, Rank Correlation Methods, Charles Griffin, London, UK, 4th edition, 1975. 
[17] D. R. Helsel and R. M. Hirsch, Statistical Methods in Water Resources, vol. 529, Elsevier, Amsterdam, The Netherlands, 1992.

[18] T. A. Buishand, "Some methods for testing the homogeneity of rainfall records," Journal of Hydrology, vol. 58, no. 1-2, pp. 11-27, 1982.

[19] D. Raes, D. Mallants, and Z. Song, "RAINBOW: a software package for analysing hydrologic data," in Hydraulic Engineering Software VI, W. R. Blain, Ed., pp. 525-534, Computational Mechanics Publication, Boston, Mass, USA, 1996.

[20] C. F. Merriam, "A comprehensive study of the rainfall on the Susquehanna Valley," Transactions American Geophysical Union, vol. 18, no. 2, pp. 471-476, 1937.

[21] W.-W. Zhao, B.-J. Fu, Q.-H. Meng, Q.-J. Zhang, and Y.-H. Zhang, "Effects of land-use pattern change on rainfall-runoff and runoff-sediment relations: a case study in Zichang watershed of the Loess Plateau of China," Journal of Environmental Sciences, vol. 16, no. 3, pp. 436-442, 2004.

[22] A. Medjerab and L. Henia, "Régionalisation des pluies annuelles dans l'Algérie nord-occidentale," Revue Géographique de l'Est, vol. 45, no. 2, pp. 1-12, 2005.

[23] H. Meddi and M. Meddi, "Variabilité des précipitations annuelles du Nord-Ouest de l'Algérie," Sécheresse, vol. 20, no. 1, pp. 57-65, 2009.

[24] A. N. Ghenim, A. Megnounif, A. Seddini, and A. Terfous, "Fluctuations hydropluviométriques du bassin versant de l'Oued Tafna à Béni Bahdel (Nord Ouest Algérien)," Sécheresse, vol. 21, no. 2, pp. 115-120, 2010.

[25] A. N. Ghenim and A. Megnounif, "Analyse des précipitations dans le Nord-Ouest Algérien," Sécheresse, vol. 24, no. 2, pp. 107114, 2013.

[26] A. N. Ghenim and A. Megnounif, "Ampleur de la sécheresse dans le bassin d'alimentation du barrage Meffrouche (NordOuest de l'Algérie)," Géographie Physique et Environnement (Physio-Géo), vol. 7, pp. 35-49, 2013.

[27] A. Dahmani and M. Meddi, "Impact of rainfall deficiency on water resources in the plain Ghriss Wilaya of Mascara (West of Algeria)," American Journal of Scientific and Industrial Research, vol. 2, no. 5, pp. 755-760, 2011.

[28] C. M. Philandras, P. T. Nastos, J. Kapsomenakis, K. C. Douvis, G. Tselioudis, and C. S. Zerefos, "Long term precipitation trends and variability within the Mediterranean region," Natural Hazards and Earth System Sciences, vol. 11, no. 12, pp. 3235-3250, 2011.

[29] H. Reiser and H. Kutiel, "Rainfall uncertainty in the Mediterranean: time series, uncertainty, and extreme events," Theoretical and Applied Climatology, vol. 104, no. 3-4, pp. 357-375, 2011.

[30] C. Maciel Vaz, "Trend analysis in annual maximum daily rainfall series," Tech. Rep., Universidade Técnica de Lisboa, Lisbon, Portugal, 2008.

[31] S. Deka, M. Borah, and SC. Kakaty, "Distributions of annual maximum rainfall series of north-east India," European Water Publications, vol. 27-28, pp. 3-14, 2009.

[32] K. A. Al-Qudah and A. A. Smadi, "Trends in maximum daily rainfall in marginal desert environment: signs of climate change," American Journal of Environmental Sciences, vol. 7, no. 4, pp. 331-337, 2011.

[33] B. Habibi, M. Meddi, and A. Boucefiane, "Analyse fréquentielle des pluies journalières maximales," Cas du Bassin ChottChergui. Nature \& Technologie, vol. 8, pp. 41-48, 2013.

[34] J. Guiot, "Sur la détermination des régions climatiques quasi homogènes," Revue de Statistique Appliquée, vol. 34, no. 2, pp. 15-34, 1986.
[35] A. Benhamrouche, D. Boucherf, R. Hamadache, L. Bendahmane, J. Martin-Vide, and J. Teixeira Nery, "Spatial distribution of the daily precipitation concentration index in Algeria," Natural Hazards and Earth System Sciences, vol. 15, no. 3, pp. 617-625, 2015.

[36] M. C. Llasat, M. Llasat-Botija, M. A. Prat et al., "High-impact floods and flash floods in Mediterranean countries: the FLASH preliminary database," Advances in Geosciences, vol. 23, pp. 47$55,2010$.

[37] A. Bakreti, I. Braud, E. Leblois, and A. Benali, "Analyse conjointe des régimes pluviométriques et hydrologiques dans le bassin de la Tafna (Algérie Occidentale)," Hydrological Sciences Journal, vol. 58, no. 1, pp. 133-151, 2013.

[38] Y. Tramblay, S. El Adlouni, and E. Servat, "Trends and variability in extreme precipitation indices over maghreb countries," Natural Hazards and Earth System Sciences, vol. 13, no. 12, pp. 32353248, 2013.

[39] M. Lazri and S. Ameur, "Analysis of the time trends of precipitation over mediterranean region," International Journal of Information Engineering and Electronic Business, vol. 6, no. 4, pp. 38-44, 2014.

[40] G. Villarini, "Analyses of annual and seasonal maximum daily rainfall accumulations for Ukraine, Moldova, and Romania," International Journal of Climatology, vol. 32, no. 14, pp. 22132226, 2012.

[41] T. S. Stephenson, L. A. Vincent, T. Allen et al., "Changes in extreme temperature and precipitation in the Caribbean region, 1961-2010," International Journal of Climatology, vol. 34, no. 9, pp. 2957-2971, 2014.

[42] IPCC, "Special Report on Managing the risks of extreme events and disasters to advance climate change adaptation(SREX)," in A Special Report of Working Group I and Working Group II of the Intergovernmental Panel on Climate Change, C. B. Field, V. Barros, T. F. Stocker et al., Eds., p. 582, Cambridge University Press, New York, NY, USA, 2012.

[43] D. H. Burn, R. Mansour, K. Zhang, and P. H. Whitfield, "Trends and variability in extreme rainfall events in British Columbia," Canadian Water Resources Journal, vol. 36, no. 1, pp. 67-82, 2011.

[44] E. M. Douglas and C. A. Fairbank, "Is precipitation in Northern New England becoming more extreme? statistical analysis of extreme rainfall in Massachusetts, New Hampshire, and Maine and updated estimates of the 100-year storm," Journal of Hydrologic Engineering ASCE, vol. 16, no. 3, pp. 203-217, 2011.

[45] S. Westra, L. V. Alexander, and F. W. Zwiers, "Global increasing trends in annual maximum daily precipitation," Journal of Climate, vol. 26, no. 11, pp. 3904-3918, 2013.

[46] M. R. Jones, S. Blenkinsop, H. J. Fowler, and C. G. Kilsby, "Objective classification of extreme rainfall regions for the UK and updated estimates of trends in regional extreme rainfall," International Journal of Climatology, vol. 34, no. 3, pp. 751-765, 2014.

[47] P. Y. Groisman, T. R. Karl, D. R. Easterling et al., "Changes in the probability of heavy precipitation: important indicators of climatic change," Climatic Change, vol. 42, no. 1, pp. 243-283, 1999.

[48] M. A. Degefu and W. Bewket, "Variability and trends in rainfall amount and extreme event indices in the Omo-Ghibe River Basin, Ethiopia," Regional Environmental Change, vol. 14, no. 2, pp. 799-810, 2014.

[49] C. Oikonomou, H. A. Flocas, M. Hatzaki, D. N. Asimakopoulos, and C. Giannakopoulos, "Future changes in the occurrence of 
extreme precipitation events in eastern Mediterranean," Global Nest Journal, vol. 10, no. 2, pp. 255-262, 2008.

[50] F. Giorgi and P. Lionello, "Climate change projections for the Mediterranean region," Global and Planetary Change, vol. 63, no. 2-3, pp. 90-104, 2008.

[51] C. Norrant and A. Douguédroit, “Tendances des précipitations mensuelles et quotidiennes dans le sud-est méditerranéen français (1950-51/1999-2000)," Climatologie, vol. 1, pp. 45-64, 2004.

[52] A. Megnounif and A. N. Ghenim, "Rainfall irregularity and its impact on the sediment yield in Wadi Sebdou watershed, Algeria," Arabian Journal of Geosciences, vol. 9, no. 4, pp. 1-15, 2016.

[53] M. De Luis, J. Raventos, J. R. Sanchez, J. C. Gonzalez, J. Cortina, and M. F. Garcia-Cano, "Event contribution to annual precipitation: a trend analysis," in Proceedings of the 2nd International Conference on Climate and Water, pp. 290-300, Espoo, Finland, 1998.

[54] A. N. Ghenim, Ecoulements et Transports Solides dans les Régions Semi-Arides, Editions Universitaires Européennes, 2012. 

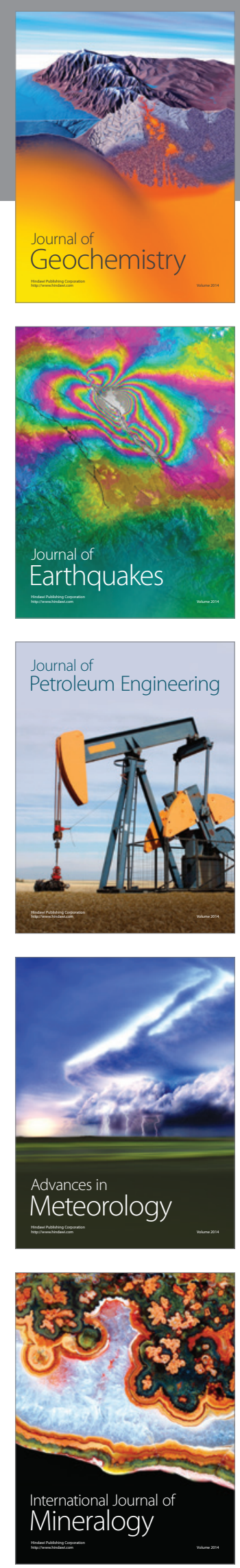
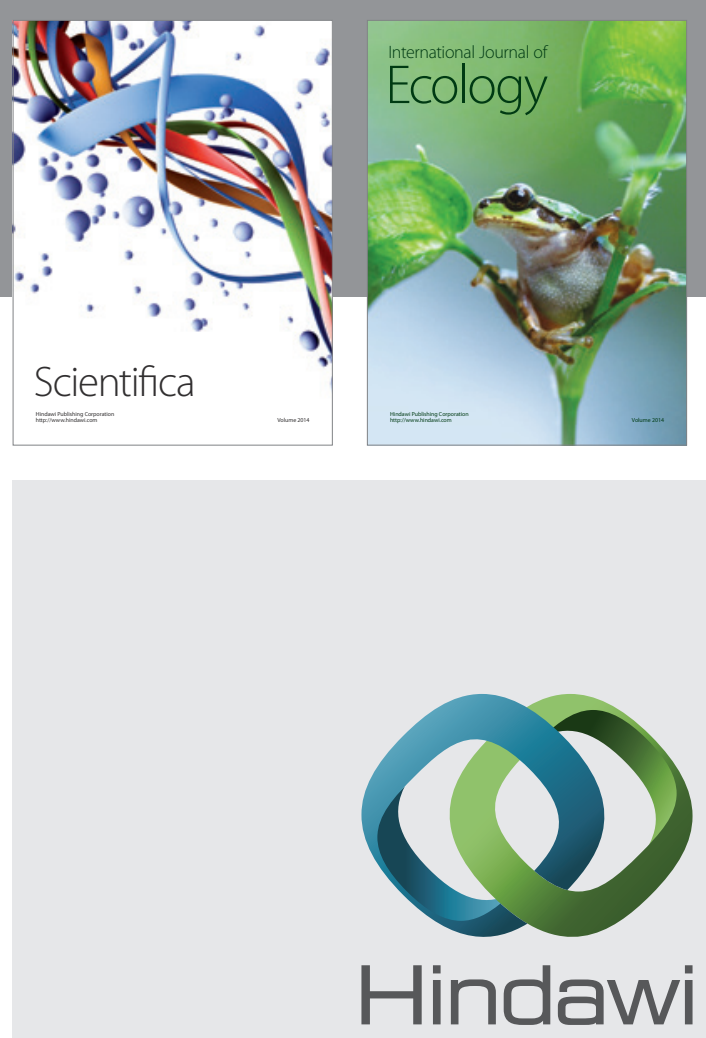

Submit your manuscripts at

http://www.hindawi.com
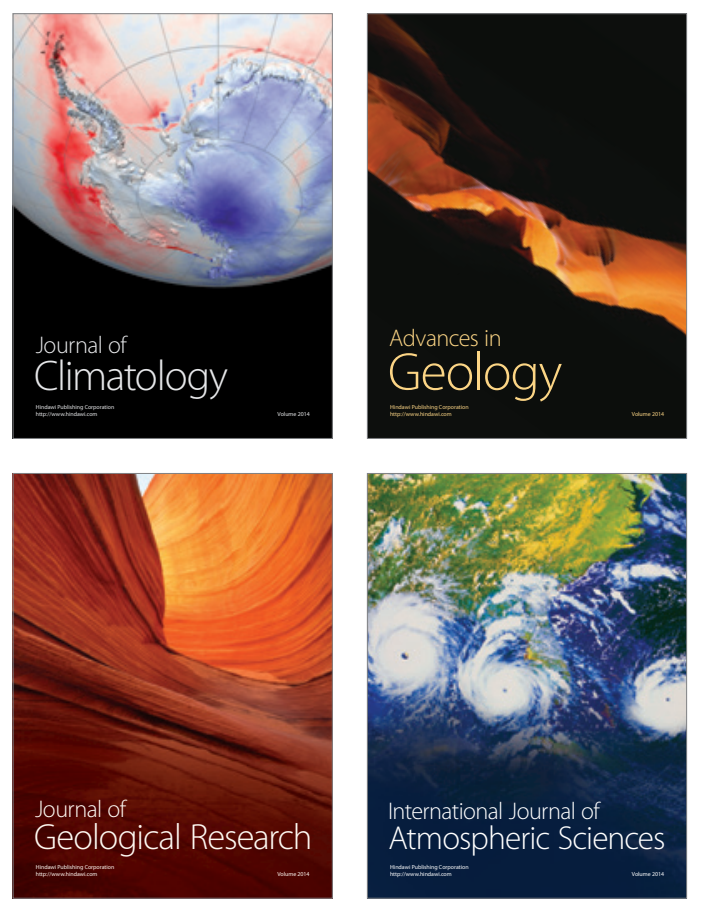

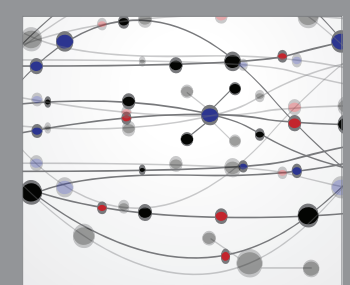

The Scientific

\section{World Journal}
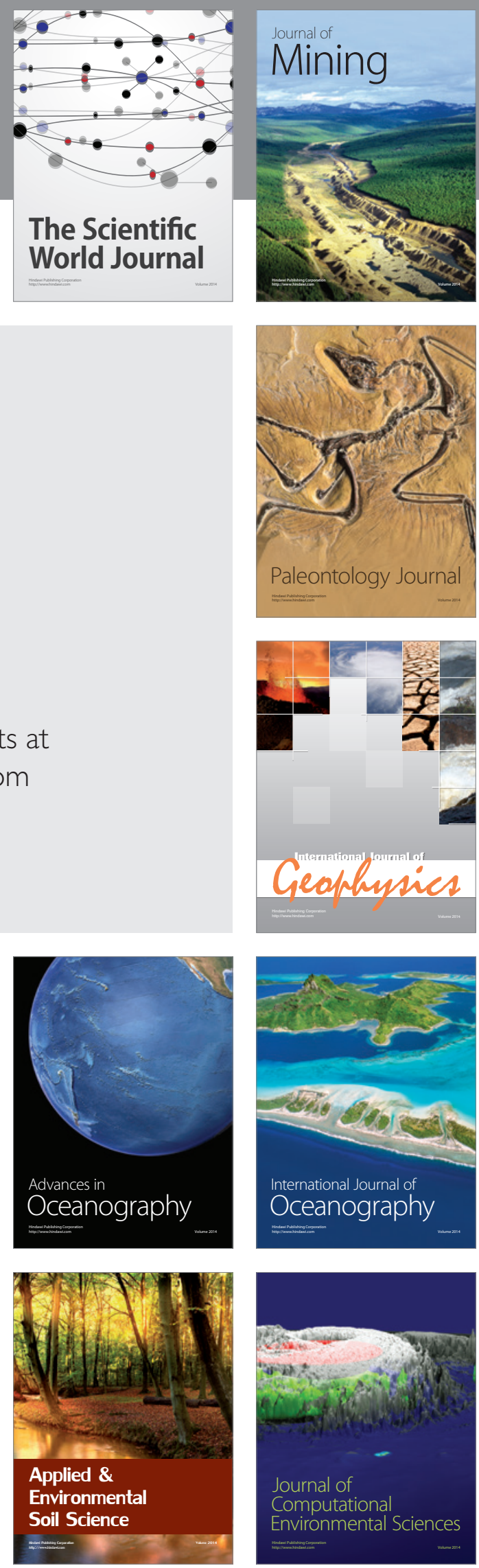